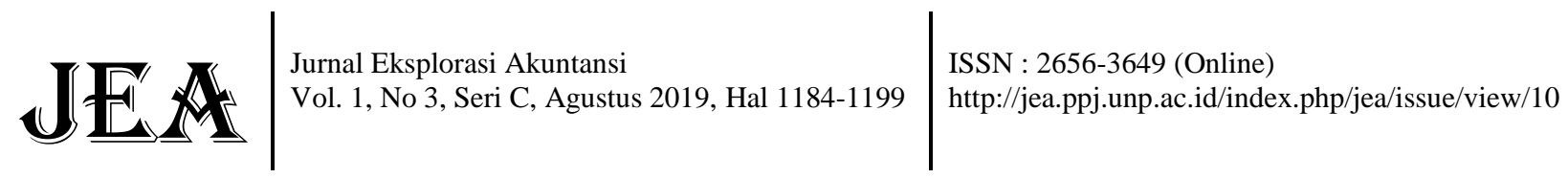

\section{PENGARUH KAPITALISASI PASAR DAN GOOD CORPORATE GOVERNANCE TERHADAP PENGUNGKAPAN CORPORATE SOCIAL RESPONSIBILITY}

(Studi Empiris Pada Perusahaan Manufaktur Yang Terdaftar di Bursa Efek Indonesia Tahun 2015-2017)

\author{
Oktavila ${ }^{1}$, Erinos NR ${ }^{2}$ \\ ${ }^{1)}$ Alumni Jurusan Akuntansi Fakultas Ekonomi, UniversitasNegeri Padang \\ 2) Jurusan Akuntansi Fakultas Ekonomi, Uni versitas Negeri Padang \\ *Korespondensi: oktavila74@gmail.com
}

\begin{abstract}
The purpose of the research is to know the market capitalization, and the good corporate governance that is proxied by the institutional ownership, the audit committe, and the commissioner size. This study uses secondary data from the company's annual report for 2015-2017. The sampling method in this study used purposive sampling with a sample of 63 manufacturing companies listed on the indonesia Stock Exchange in 2015-2017. The analysis used in this multiple linear regression analysis. The results showed that the market capitalization and commissioner size had a significant positive effect on corporate social responsibility disclosure, while the audit committe has a positive and insignificant effect on corporate social responsibility disclosure, and institutional ownership has significant negative effect on corporate social responsibility disclosure.
\end{abstract}

Keywords: Corporate Social Responsibility; Market Capitalization; Institutional Ownership; Audit Committe; and Commissioner Size.

How to cite (APA $6^{\text {th }}$ style)

Oktavila \& Erinos, N.R. (2019). Pengaruh Kapitalisasi Pasar dan Good Corporate Governance terhadap Pengungkapan Corporate Social Responsibility (Studi Empiris pada Perusahaan Manufaktur yang Terdaftar di Bursa Efek Indonesia Tahun 2015-2017). Jurnal Eksplorasi Akuntansi, 1(3), Seri C, 1184-1199.

\section{PENDAHULUAN}

Tanggung jawab sosial perusahaan atau lebih dikenal dengan istilah Corporate Social Responsibility (CSR) merupakan sebuah tindakan yang dilakukan perusahaan sebagai bentuk tanggung jawabnya kepada lingkungan, sosial, dan masyarakat setempat yang berada disekitar perusahaan atas dampak dari kegiatan yang dilakukan perusahaan. Pelaksanaan CSR yang semulanya dianggap sebagai kewajiban yang akan menambah biaya atau beban perusahaan, namun secara jangka panjang, tanggung jawab sosial dapat mendatangkan keuntungan atau manfaat tertentu. CSR yang awalnya dianggap beban akan berubah menjadi suatu investasi strategis, karena mendatangkan keuntungan yang tidak ada habisnya bagi perusahaan (Jayanti dan Husaini, 2018). Melalui Pengungkapan CSR perusahaan dapat membangun reputasinya, seperti meningkatkan posisi merk perusahaan, bidang usaha, maupun meningkatkan citra perusahaan dimata publik. 
Surwardjono (2005) menyatakan bahwa kata pengungkapan memiliki arti secara umum tidak menutupi atau tidak menyembunyikan. Pengungkapan CSR adalah penyampaian suatu informasi mengenai kegiatan yang dilakukan oleh perusahaan atas dampak sosial dan lingkungan yang ditimbulkannya. Pasaribu dkk (2015) menjelaskan tujuan dilakukannya CSR adalah agar suatu perusahaan mendapatkan nilai lebih dibandingkan dengan perusahaan lainnya dan agar dapat memenuhi harapan masyarakat, sehingga perusahaan memperoleh legitimasi dari masyarakat sekaligus perusahaan juga dapat menarik simpati investor. Pengungkapan CSR juga digunakan perusahaan untuk menciptakan pembangunan ekonomi berkelanjutan yang mana perusahaan tidak hanya memikirkan keuntungan sendiri tetapi juga memikirkan dampak yang terjadi akibat dari kegiatan perusahaan baik dampak sosial atau lingkungan (Susilo, 2015).

Pengungkapan CSR juga digunakan untuk melaporkan isu-isu ekonomi, sosial dan lingkungan kepada stakeholder perusahaan dengan tujuan untuk menjaga hubungan baik perusahaan dengan stakeholder-nya agar stakeholder perusahaan tidak merasa khawatir terhadap keberlanjutan perusahaan di masa yang akan datang. Kegiatan CSR pada umumnya akan diungkapkan dalam laporan tahunan yang diterbitkan. Pelaporan tanggung jawab sosial perusahaan dalam laporan tahunan perusahaan diharapkan perusahaan memperoleh legitimasi atas peran sosial dan kepedulian lingkungan yang telah dilakukan oleh perusahaan, sehingga perusahaan memperoleh dukungan dari masyarakat dan keberlangsungan hidup perusahaan dapat diperoleh (Gray, 2006 dalam Aggraeni dan Djakman, 2017).

Peraturan mengenai Corporate Social Responsibility di Indonesia telah diatur dalam UU Nomor 40 tahun 2007 tentang Perseroan Terbatas (PT) dan Peraturan Pemerintah No. 47 tahun 2012 tentang tanggung jawab sosial dan lingkungan PT. UU No. 40 tahun 2007 menjelaskan perusahaan yang menjalankan kegiatan usahan yang berhubungan dengan sumber daya alam wajib melakukan tanggung jawan sosial dan lingkungan. Pasal 66 ayat 2c UU No. 40 tahun 2007 telah dijelaskan semua perseroan wajib untuk melaporkan pelaksanaan tanggung jawab sosial dan lingkungan dalam laporan tahunan perusahaan. Salah satu Faktor yang dapat mempengaruhi pengungkapan CSR adalah kapitalisasi pasar.

Rahayu dan Rahayu (2013) mengatakan bahwa Kapitalisasi pasar merupakan harga dari keseluruhan saham yang beredar dipasar. Semakin tinggi harga saham maka semakin banyak pula investor yang ingin bergabung sehingga manajemen akan mengungkapkan informasi tanggung jawab sosial perusahaan lebih rinci. Indraswari dan Mimba (2017), Sufian (2012) menunjukan bahwa terdapat pengaruh positif signifikan antara kapitalisasi pasar terhadap pengungkapan CSR. Berbeda dengan penelitian dari Deitina (2015) dan Rahayu dan Rahayu (2013) yang menemukan bahwa kapitalisasi pasar tidak berpengaruh positif signifikan terhadap pengungkapan CSR.

Tata kelola perusahaan (Good Corporate Governance) menjadi faktor berikutnya yang mempengaruhi pengungkapan CSR. Praktik dan pengungkapan CSR merupakan konsekuensi dari struktur Good Corporate Governance (GCG), yang prinsipnya menjelaskan bahwa perusahaan perlu memperhatikan kepentingan para pemangku kepentingan, sesuai dengan aturan yang ada dan menjalin kerjasama yang aktif dengan para pemangku kepentingan demi kelangsungan hidup jangka panjang perusahaan (Wartyna dan Apriwenni, 2018). Indikator Good corporate governace dalam penelitian ini adalah kepemilikan institusional, komite audit, dan ukuran dewan komisaris

Kepemilikan institusional merupakan saham yang dimiliki oleh institusi atau lembaga seperti bank, perusahaan investasi, perusahaan asuransi dan kepemilikan lainnya dalam suatu perusahaan. Pemegang saham institusional juga memiliki sumber daya, kemampuan, pengalaman, dan kesempatan untuk menganalisis kinerja dan tindakan manajemen. Kepemilikan institusional yang besar akan berdampak dan berpengaruh pada keputusan manajemen yang akan diambil (Laksamitaningrum dan Purwanto, 2013). Salah satu 
keputusan manajemen adalah pengungkapan informasi tanggung jawab sosial perusahaan. hal ini didukung oleh penelitian dari Majeed, et al (2015) dalam penelitiannya mengenai CSR menyatakan bahwa kepemilikan institusional berpengaruh positif signifikan terhadap pengungkapan CSR.

Komite audit merupakan komite yang membantu dewan pengawas atau komisaris dalam memastikan sistem pengendalian internal terlaksana dengan efektif dan memantau efektivitas pelaksanaan tugas auditor eksternal dan internal, serta menjadi penghubung komunikasi antara dewan komisaris dengan auditor eksternal (Pasaribu dkk, 2015). Penelitian Krisna dan Surhardianto (2016), Pasaribu dkk (2015) dan Khan, et al (2013) menemukan bahwa komite audit berpengaruh positif signifikan terhadap pengungkapan CSR. Berbeda dengan Yusran, dkk (2018), Paramita dan Marsono (2014), Rizki, dkk (2014) yang menunjukan bahwa jumlah komite audit tidak memiliki pengaruh positif signifikan terhadap pengungkapa CSR. Hal ini terjadi karena komite audit yang pada umumnya beranggota tiga orang hanya sebagai formalitas untuk memenuhi peraturan OJK (Otoritas Jasa Keuangan) mengenai pembentukan dan pedoman pelaksanaan kerja komite audit, tanpa mempertimbangkan efektivitas dan komplektivitas perusahaan.

Ukuran dewan komisaris menjadi faktor selanjutnya dalam pengungkapan CSR. Dewan komisaris sebagai badan perusahaan yang bertugas dan bertanggung jawab secara kolektif dalam mengawasi dan memberikan nasihat kepada dewan direksi serta memantau perusahaan telah melaksanakan GCG (Pasaribu dkk, 2015). Dewan komisaris akan memberikan tekanan kepada manajemen untuk mengungkapkan CSR agar kualitasnya semakin baik sehingga hubungan antara perusahaan dan pemangku kepentingan semakin lebih baik lagi (Sembiring, 2006). Penelitian dari Susilo (2015), Yusran, dkk (2018), Pasaribu dkk (2015) menemukan ukuran dewan komisaris berpengaruh signifikan terhadap pengungkapan CSR. Berbeda dengan Jayanti dan Husaini (2018), dan Nurfadiah dan Sagara (2015) menemukan ukuran dewan komisaris tidak memiliki pengaruh signifikan terhadap pengungkapan CSR.

Perbedaan penelitian ini dengan penelitian terdahulu yang dilakukan oleh Yusran, dkk (2018) adalah adanya penambahan variabel yang diduga mempengaruhi pengungkapan CSR. Variabel ini masih jarang diteliti oleh peneliti-peneliti sebelumnya adalah variabel kapitalisasi pasar. Standar yang digunakan dalam pengungkapan CSR dalam penelitian terdahulu menggunakan G3 versi 3.0 dengan 78 item pengungkapan pada standarnya, sedang dalam penelitan ini menggunakan standar terbaru yang dikeluarkan oleh Global Reporting Initiative (GRI) yaitu G4 versi 4.0 yang diterbitkan pada tahun 2013. Standar pada G4 item pengungkapan semakin rinci dengan 91 item pengungkapan. Penelitian ini menggunakan sampel seluruh perusahaan manufaktur yang terdaftar di Bursa Efek Indonesia (BEI) tahun 2015-2017.

Alasan pemilihan perusahaan manufaktur sebagai sampel penelitian adalah pertama, karena industri manufaktur lebih dominan daripada industri lainnya. Kedua, perusahaan manufaktur lebih banyak memperoleh perhatian publik akibat dari banyak dampak yang ditimbulkan akibat aktivitas perusahaan tersebut, sehingga memungkinkan perusahaan untuk mengungkapkan informasi yang lebih luas. Dari latar belakang yang telah diuraikan di atas mendasari peneliti untuk melakukan penelitian dengan judul "Pengaruh Kapitalisasi Pasar dan Good Corporate Governance Terhadap Pengungkapan Corporate Social Responsibility".

\section{KAJIAN TEORI}

\section{Teori Legitimasi (Legitimacy Theory)}

Teori legitimasi merupakan salah satu teori yang mendasari insentif perusahaan yang sukarela mengungkapkan laporan pertanggungjawaban sosial dan lingkungan (Luo et al, 2013). Teori legitimasi didasari oleh "kontrak sosial" antara perusahaan dengan masyarakat 
dimana perusahaan beroperasi dan menggunakan sumber daya (Ghozali dan Chariri, 2007). Kontrak sosial ini menjelaskan harapan masyarakat tentang tata cara perusahaan dalam melakukan aktivitas. Kontrak sosial dapat bersifat implisit yaitu persyaratan legal dan juga dapat bersifat eksplisit yaitu kontrak sosial yang tidak tercantum dalam persyaratan legal. Indraswari dan Mimba (2017) menjelaskan teori legitimasi merupakan organisasi yang mencari untuk menjamin operasi berjalan dan berada pada norma yang ada di lingkungan masyarakat yang dapat dicapai melalui pengungkapan CSR. Melalui pengungkapan tersebut diharapkan perusahaan mendapatkan legitimasi dari masyarakat yang akan berdampak pada keberlangsungan hidup perusahaan.

\section{Teori Pemangku Kepentingan Stakeholder Theory)}

Anggraeni dan Djakman (2017) menjelaskan bahwa stakeholder merupakan kelompok atau individu yang mempunyai atau menyatakan, hak, atau kepentingan di dalam perusahaan dan aktivitasnya, baik di masa lalu, sekarang, maupun yang akan datang. Roberts (1992) dalam Anggareni dan Djakman (2017) menyebutkan bahwa stakeholder perusahaan meliputi pemegang saham, pegawai, pelanggan, kreditur, organisasi masyarakat, pemerintah serta pemasok.

Perusahaan juga harus memperhatikan kepentingan stakeholder untuk kemudian menjalin komunikasi dengan mereka sebagai salah satu alat pengerat hubungan kedua belah pihak. Perhatian yang dapat diberikan perusahaan kepada stakeholder dengan cara menerapkan program CSR, perusahaan yang melaksanakan CSR akan memperhatikan dampak dari aktivitas yang dilakukan terhadap kondisi lingkungan dan sosial dan berupaya agar memberikan dampak positif kepada masyarakat dan stakeholder lainnya. Teori stakeholder menjelaskan bahwa perusahaan harus memberikan perhatian kepada stakeholder, karena stakeholder dapat memberikan pengaruh dan dipengaruhi oleh perusahaan berkaitan dengan kebijakan dan aktivitas yang dilaksanakan (Nugraha dan Andayani, 2013).

\section{Teori Agensi (Agency Theory)}

Teori keagenan adalah teori yang menjelaskan hubungan antara agen dan prinsipal. Wartyna dan Apriwenni (2018) inti dari hubungan keagenan adalah adanya pemisahaan antara kepemilikan (principal/investor) dengan pengendalian (agen/manajer). Teori agensi di buat untuk memecahkan masalah yang muncul apabila adanya ketidaklengkapan informasi pada saat melakukan kontrak antara agen dan prinsipal. Dalam teori agensi, agen memiliki informasi yang lebih banyak mengenai perusahaan ketimbang dengan prinsipal sehinga hal ini dapat menjadi peluang bagi agen untuk menguntungkan diri sendiri. Perbedaan informasi yang diperoleh oleh agen dan prinsipal ini yang akan menyebabkan munculnya asimetri informasi.

Teori agensi menjelaskan perusahaan yang mengalami biaya kontrak dan biaya pengawasan yang rendah cenderung melaporkan laba bersih rendah atau akan mengeluarkan biaya-biaya yang dapat meningkatkan reputasi perusahaan di mata masyarakat. Wujud pertanggungjawaban manajer sebagai agen akan berupaya memenuhi semua keinginan para prinsipal, salah satu cara dengan melaksanakan program CSR. Program CSR dapat menjadi sinyal yang akan mengalihkan perhatian investor dari pengawasan manipulasi laba atau isuisu lainnya sehingga harga saham di pasar modal meningkat seiring meningkatnya kepercayaan investor terhadap transparansi informasi yang diungkapakan oleh perusahaan.

\section{Corporate Social Responsibility}

Corporate Social Responsibility (CSR) merupakan tindakan perusahaan untuk berbuat baik kepada masyarakat diluar paksaan hukum dan tujuan utama perusaan yaitu untuk kepentingan stakeholder-nya (Majeed et al, 2015). The Wold Business Council for Sustainable 
Development (WBCSD), menjelaskan CSR atau tanggung jawab sosial perusahaan merupakan komitmen perusahaan untuk memberikan kontribusi bagi pembangunan ekonomi berkelanjutan, melalui kerja sama dengan karyawan serta perwakilan mereka, keluarga mereka, komunitas setempat maupun masyarakat umum untuk meningkatkan kualitas hidup dengan memberikan imbal balik bagi kelangsungan bisnis perusahaan dan untuk pembangunan.

\section{Pengungkapan Corporate Social Responsibility}

Kata pengungkapan secara umum memiliki makna tidak menutupi atau tidak menyembunyikan secara konseptual, pengungkapan merupakan bagian integral dari laporan keuangan. secara teknis, pengungkapan adalah langkah terakhir statemen keuangan (Ghozali dan Chariri, 2007). Tujuan pengungkapan secara umum adalah menyajikan informasi yang dipandang perlu untuk mencapai tujuan pelaporan keuangan dan melayani berbagai pihak yang mempunyai kepentingan berbeda. Pengungkapan ada yang bersifat sukarela (voluntary) dan bersifat wajib (mandatory). Bersifat sukarela merupakan pengungkapan informasi melebihi persyaratan minimum dari peraturan yang berlaku, sedangkan bersifat wajib yaitu pengungkapan informasi wajib dilakukan oleh perusahaan yang didasarkan pada peraturan atau standar tertentu (Ghozali dan Chariri, 2007).

\section{Good Corporate Governance}

Corporate Governance adalah penerapan tata kelola perusahaan yang baik. Efektivitas tata kelola perusahaan menggambarkan bahwa perusahaan mendukung adanya perkembangan yang berkelanjutan melalui kualitas informasi yang diungkapkan. Organisation for Economic Co-operation and Development (OECD) menjelaskan Corporate Governance merupakan sistem untuk pengawasi dan mengarahkan perusahaan atau entitas bisnis melalui mekanisme Corporate Governance (Hikmah, et al, 2011).

Mekanisme pengawasan Corporate Governance terdapat dua kelompok yaitu mekanisme eksternal dan mekanisme internal. Mekanisme eksternal adalah cara bagaimana mempengaruhi perusahaan selain dengan mekanisme internal, seperti mekanisme pasar dan pengendalian perusahaan. Mekanisme internal adalah cara mengendalikan perusahaan dengan menggunakan struktur dan proses internal seperti kepemilikan saham institusional, jumlah komite audit, dan ukuran dewan komisaris (Ningsih, 2017).

\section{HIPOTESIS}

\section{Kapitalisasi Pasar}

Rahayu dan Rahayu (2013) menjelaskan bahwa kapitalisasi pasar adalah istilah bisnis yang menggambarkan harga keseluruhan dari sebuah saham perusahaan. perusahaan yang mempunyai harga saham yang tinggi akan semakin banyak investor yang berminat untuk bergabung serta mendapatkan banyak perhatian dari para investor, sehingga perusahaan akan mendapatkan tingkat kapitalisasi pasar yang besar (Rahayu dan Rahayu, 2013). Perusahaan yang berkembang pesat akan menyebabkan adanya terkaitan masyarakat terhadap perusahaan dan lebih memperhatikan perusahaan (Indraswari dan Mimba, 2017). Perusahan yang besar akan mengalami tekanan yang jauh lebih kuat untuk memenuhi berbagai tuntutan peraturan dan ketentuan sehingga perusahaan diharapkan mampu menunjukan akuntabilitas secara lebih luas kepada seluruh pihak yang berkepentingan terhadap perusahaan.

Perusahaan dengan kapitalisasi pasar yang besar mempunyai keterkaitan yang lebih luas dengan masyarakat dan stakeholder lainnya sehingga pihak manajemen akan melaporkan informasi tanggung jawab sosial lebih rinci (Indraswari dan Mimba, 2017). Melalui pengungkapan tersebut diharapkan perusahaan akan memperoleh legitimasi dari masyarakat yang akan berdampak pada kelangsungan hidup perusahaan (Rahayu dan Rahayu, 2013). 
Uraian diatas sejalan dengan penelitian Sufian (2012) serta Indraswari dan Mimba (2017) yang mengatakan kapitalisasi pasar menjadi penentu dalam pengungkapan Corporate Social Responsibility. Sehingga hipotesis pertama yang diajukan sebagai berikut:

H1: Kapitalisasi pasar berpengaruh positif terhadap pengungkapan Corporate Social Responsibility

\section{Kepemilikan Institusional}

Investor institusional didefinisikan sebagai lembaga atau instansi yang bergerak dalam bidang asuransi, bank, dana pensiun maupun perusahaan investasi. Teori stakeholder menjelaskan tiap stakeholder turut dalam menentukan kinerja perusahaan, termasuk kinerja sosial. Institusi dianggap sebagai pihak yang mampu dalam mengelola dan mengawasi investasinya, baik dari segi sistem informasi, pengetahuan, maupun sumber daya yang dimiliki. Investor institusioanal umumnya merupakan pemegang saham yang cukup besar karena memiliki pendanaan yang besar. Kepemilikan institusioanal yang tinggi akan menimbulkan usaha pengawasan yang lebih besar oleh pihak investor sehingga dapat menghalangi perilaku opportunistic manajer (Pasaribu dkk, 2015). Kepemilikan institusional yang semakin besar maka semakin besar pula tekanan terhadap manajemen untuk mengungkapkan tanggung jawab sosial perusahaan.

Susunan kepemilikan institusional yang besar sangat berpengaruh pada keputusan manajemen yang akan diambil. Salah satu keputusannya adalah pengungkapan informasi tanggung jawab sosial perusahaan. Rahayu dan Rahayu (2013) dalam penelitiannya menunjukan bahwa kepemilikan institusional berpengaruh signifikan terhadap pengungkapan CSR pada perusahaan manufaktur go public yang terdaftar di BEI tahun 2010-2011. Berdasarkan uraian diatas hipotesis penelitian yang diajukan sebagai berikut:

$\mathrm{H}_{2}$ : Kepemilikan institusional berpengaruh positif terhadap pengungkapan Corporate Social Responsibility.

\section{Komite Audit}

Komite audit memiliki tugas sebagai fasilitator bagi dewan komisaris. Tugas tersebut adalah memastikan sistem pengendalian internal perusahaan berjalan dengan efektif agar manajemen siap menjalankan kegiatan bisnis yang sehat sesuai dengan prinsip kehati-hatian, dan memastikan efektivitas pelaksanaan tugas baik audit internal maupun auditor eksternal telah dilaksanakan sesuai standar auditing yang berlaku (Krisna dan Suhardianto, 2016). Berdasarkan tugas tersebut keberadaan komite audit sebagai indikasi pengawasan atau monitoring kualitas tinggi dan berpengaruh signfikan dalam menyediakan informasi yang lebih kepada pemakai laporan keuangan.

Perusahaan yang memiliki komite audit membuat para stakeholder mendapatkan jaminan bahwa kegiatan perusahaan telah dikendalikan dengan baik dan kegiatan perusahaan baik keuangan maupun non keuangan juga telah diungkapkan dalam laporan keuangan dan tahunan perusahaan (Krisna dan Suhardianto, 2016). Semakin banyak ukuran komite audit diharapkan proses pengawasan akan dilakukan semakin baik dan pengungkapan tanggung jawab sosial akan semakin luas. uraian diatas sejalan dengan penelitian Pasaribu dkk (2015) yang menunjukan adanya pengaruh positif jumlah komite audit terhadap pengungkapan Corporate Social Responsibility. Berdasarkan uraian diatas hipotesis penelitian yang diajukan sebagai berikut:

H3: Komite audit berpengaruh positif terhadap pengungkapan Corporate Social Responsibility 


\section{Ukuran Dewan Komisaris}

Dewan komisaris sebagai perwakilan para pemilik saham berperan sebagai pengawas kinerja perusahaan, termasuk kinerja sosial perusahaan (Krisna dan Suhardianto, 2016). Hal ini dilakukan untuk memenuhi kepentingan seluruh pemangku kepentingan. Perusahaan yang memiliki dewan komisaris yang banyak dapat mencerminkan adanya pengawasan yang baik dalam suatu perusahaan. Dewan komisaris akan memberikan dorongan kepada manajemen untuk lebih transparan dalam pelaporan keuangan dan pengungkapan informasi kegiatan perusahaan dalam laporan tahunan perusahaan termasuk pengungkapan Corporate Social Responsibility (CSR) (Terzaghi, 2012).

Hal ini berarti bahwa semakin banyak jumlah dewan komisaris dalam perusahaan semakin baik pula pengawasan terhadap manajemen serta pengungkapan Corporate Social Responsibility (CSR) dalam laporam keuangan dan tahunan semakin luas. Hal tersebut sejalan dengan penelitian Terzaghi (2012), dan Pasaribu dkk (2015) yang menunjukan bahwa ukuran dewan komisaris berpengaruh positif terhadap pengungkapan corporate social responsibility. Berdasarkan uraian diatas maka hipotesis yang diajukan sebagai berikut:

$\mathbf{H}_{4}$ : Ukuran dewan komisaris berpenagruh positif terhadap pengungkapan corporate social responsibility

\section{METODE PENELITIAN}

\section{Jenis Penelitian}

Jenis penelitian ini adalah menggunakan penelitian kausatif dengan pendekatan kuantitatif. Penelitian kausatif merupakan jenis penelitian dengan karakteristik masalah berupa hubungan sebab akibat antara dua variabel atau lebih. Populasi dalam penelitian ini adalah seluruh perusahaan manufaktur yang terdaftar di Bursa Efek Indonesia (BEI) dari tahun 2015-2017. Sampel yang digunakan dalam penelitian ini menggunakan teknik purposive sampling yang memiliki kriteria tertentu seperti (1) perusahaan manufaktur yang terdaftar di Bursa Efek Indonesia (BEI) selama periode 2015-2017, (2) perusahaan manufaktur yang menerbitkan dan mempublikasikan laporan tahunan secara lengkap selama periode 2015-2017, (3) perusahaan manufaktur yang mengungkapkan CSR dalam laporan tahunan selama periode 2015-2017, dan (4) perusahaan yang memiliki data lengkap terkait variabel-variabel yang digunakan dalam penelitian.

Jenis data dalam penelitian ini menggunakan data dokumenter. Data dokumenter merupakan data yang didapatkan dari laporan tahunan perusahaan untuk periode 205-2017 pada perusahaan-perusahaan manufaktur yang terdaftar di Bursa Efek Indonesia (BEI). Sumber data yang digunakan adalah data sekunder yaitu data kuantitatif yang diperoleh dari objeknya secara tidak langsung. Sehingga jumlah sampel yang digunakan dalam penelitian ini sebanyak 189 laporan tahunan dari 63 perusahaan.

\section{Definisi Operasional dan Pengukuran Variabel Penelitian Pengungkapan Corporate Social Responsibility (CSR)}

Pengungkapan CSR merupakan proses pengkomunikasian dampak sosial dan lingkungan atas tindakan-tindakan ekonomi perusahaan pada kelompok-kelompok tertentu dalam masyarakat dan pada masyarakat secara keseluruhan (Rizki dkk, 2014). Indikator CSR dalam penelitian ini merujuk pada The Global Reporting Initiative (GRI) generasi keempat (G4). GRI G4 memiliki 9 indikator dalam kategori ekonomi, 48 indikator kategori sosial dan 34 indikator lingkungan. CSR diukur dengan metode content analysis, yaitu metode yang dapat mengubah informasi dalam bentuk kualitatif menjadi informasi dalam bentuk kuantitatif dengan cara kodifikasi (Abbot dan Monsen, 1979 dalam Anggraeni dan Djakman, 2017).

CSR dihitung menggunakan skala 0-1 untuk setiap indikator informasi yag diungkapkan, pengukuran diberi nilai 0 jika tidak mengungkapkan item sesuai item GRI, 1 
jika perusahaan mengungkapkan item sesuia item GRI. Menghitung indeks pengungkapan CSR perusahaan dengan menjumlahkan skor pengungkapan CSR setiap perusahaan dibagi dengan total skor pengungkapan maksimum. Rumusnya sebagai berikut:

Keterangan :

$$
\mathrm{CSRI}_{\mathrm{j}}=\frac{\sum \mathrm{X}_{\mathrm{ij}}}{\mathrm{n}_{\mathrm{j}}}
$$

$\mathrm{CSRI}_{\mathrm{j}}$ : Corporate Social Responsibility Disclosure Index perusahaan $\mathrm{j}$

$\sum \mathrm{X}_{\mathrm{ij}} \quad$ : Jumlah skor pengungkapan CSR perusahaan

$\mathrm{n}_{\mathrm{j}} \quad$ : skor maksimum pengungkapan CSR perusahaan

\section{Kapitalisasi Pasar}

Kapitalisasi pasar merupakan nilai saham perusahaan yang beredar dipasar. Mengukur kapitalisasi pasar dapat dilihat dengan cara menghitung harga saham di bursa saham dikali dengan jumlah saham yang beredar.

KpPsr : harga saham di bursa saham x jumlah saham yang beredar

\section{Kepemilikan Institusional}

Kepemilikan institusional adalah saham perusahaan yang dimiliki oleh lembaga atau institusi (bank, perusahaan investasi, perusahaan asuransi, atau intitusi lainnya) kecuali anak perusahaan dan institusi lain yang memiliki hubungan istimewa (perusahaan afiliasi dan perusahaan asosiasi). Mengukur Kepemilikan institusional dengan menggunakan indikator persentase jumlah saham yang dimiliki oleh institusi dari seluruh modal saham yang beredar.

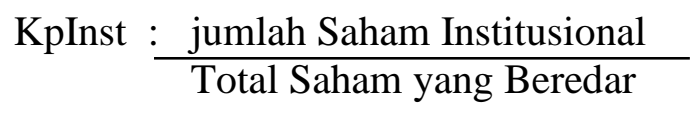

\section{Komite Audit}

Komite audit adalah komite yang berada dalam suatu perusahaan. komite audit diukur dengan cara menghitung jumlah total anggota komite audit daam suatu perusahaan yang terdapat dalam laporan tahunan perusahaan.

Keterangan:

$$
\text { KOMA : SUM_KOMA }
$$

KOMA : komite audit

SUM_KOMA : jumlah anggota komite audit dalam perusahaan

\section{Ukuran Dewan Komisaris}

Ukuran dewan komisaris diukur denagn menghitung jumlah dari seluruh anggota dewan komisaris di dalam perusahaan yang terdapat dalam laporan tahunan perusahaan, dengan rumus sebagai berikut:

$$
\mathrm{UDK}=\sum \mathrm{D} \_\mathrm{KOM}
$$

Keterangan:
UDK
: Ukuran Dewan Komisaris
$\sum$ D_KOM : Jumlah Seluruh Anggota Dewan Komisaris 


\section{HASIL DAN PEMBAHASAN}

\section{Statistik Deskriptif}

Berdasarkan hasil analisis statistik deskriptif menunjukan bahwa nilai rata-rata (mean) pengungkapan Corporate Social Responsibilty (CSR) sebesar 0,1263 dengan nilai standar deviasi sebesar 0,04781. Nilai minimum (terendah) CSR sebesar 0,07 atau 7\% dan nilai maksimum sebesar 0,25 atau $25 \%$. Variabel kapitalisasi pasar memperoleh nilai rata-rata (mean) sebesar 26.482.926,27 dengan nilai standar deviasi sebesar 83.456.637.668. Nilai minimum (terendah) kapitalisasi pasar sebesar 30.100.000.000 sedangkan nilai maksimum (tertinggi) kapitalisasi pasar sebesar 550.184.503.737.000.

Variabel kepemilikan institusional memperoleh nilai rata-rata (mean) sebesar 0,193741 dan nilai standar deviasi sebesar 0,1823348. Nilai minimum (terendah) kepemilikan institusional sebesar 0,0001 dengan nilai maksimum (tertinggi) sebesar 0,8162. Variabel komite audit memiliki nilai rata-rata (mean) sebesar 3,08 dan nilai standar deviasi sebesar 0,341. Nilai minimum (terendah) sebesar 2 dan nilai maksimum (tertinggi) sebesar 4 . Variabel ukuran dewan komisaris memiliki nilai rata-rata (mean) sebesar 4,55 dengan nilai standar deviasi sebesar 1,928. Nilai minimum (terendah) variabel ukuran dewan komisaris sebesar 2 dengan nilai maksimum (tertinggi) sebesar 12.

\section{Uji Asumsi Klasik}

\section{Uji Normalitas}

Uji normalitas digunakan untuk menguji apakah suatu residual atau variabel penggangu dalam model regresi berdistribusi normal atau tidak. Uji normalitas dalam penelitian ini menggunakan grafik P-Plot yang dapat dilihat pada lampiran. Setelah dilakukannya pengolahan data didapatkan hasil yang menunjukan bahwa data terdistribusi secara normal.

\section{Uji Multikolinearitas}

Uji multokolinearitas diuji menggunakan cara menganalisis matrik korelasi antar variabel independen dan perhitungan nilai tolerancei dan VIF yang dapat dilihat pada lampiran. hasil uji multikolinieritas didapatkan nilai tolerance memiliki nilai lebih tinggi dibandingkan dengan $10 \%$ atau 0,10 yang menunjukan bahwa tidak ada korelasi antar variabel independen. Hal tersebut juga dapat dilihat dari nilai VIF, hasil menunjukan tidak ada variabel yang mempunyai nilai VIF lebih dari 10 sehingga dapat disimpulkan bahwa tidak ada gejala multikolinieritas dalam regresi (Ghozali, 2011).

\section{Uji Heteroskedastisitas}

Uji heteroskedastisitas dalam penelitian ini menggunakan grafik scatterplot yang dapat dilihat pada lampiran. hasil pengolahan data menunjukan titik-titik menyebar dengan tidak seimbang dan tidak menciptakan pola secara jelas diatas maupun dibawah 0 pada sumbu $\mathrm{Y}$, sehingga tidak terjadi gejala heteroskedastisitas.

\section{Uji Autokorelasi}

Uji autokorelasi dalam penelitian ini menggunakan Durbin-Watson yang dapat dilihat pada lampiran nilai Durbin Watson sebesar 0,756 yang berada diantara -2 dan 2 yaitu berada pada daerah tidak ada autokorelasi.

\section{PENGUJIAN HIPOTESIS}

\section{Analisis Regresi Berganda}

Berdasarkan hasil uji regresi linear berganda maka persamaan regresi linear berganda dapat dituliskan sebagai berikut: 


$$
\mathrm{CSR}=-0,149+0,008 \mathrm{LN} \_\mathrm{KpPsr}-0,032 \mathrm{KpInst}+0,012 \mathrm{KOMA}+0,005 \mathrm{UDK}+{ }^{\mathrm{e}}
$$

\section{Uji Koefisien Determinan $\left(\mathbf{R}^{2}\right)$}

Koefisien determinasi diketahui bahwa nilai adjusted $\mathrm{R}^{2}$ adalah 0,311 , hal tersebut menunjukan bahwa 31,1\% pengungkapan CSR mampu dijelaskan oleh ke empat variabel independen dalam penelitian yaitu variabel kapitalisasi pasar, kepemilikan institusional, komite audit dan ukuran dewan komisaris. Sedangkan 68,9\% pengungkapan CSR dijelaskan oleh variabel lain diluar model penelitian. Nilai standar error of estimate (SEE) sebesar 0,03968 nilai SEE semakin kecil maka prediksi variabel dependen akan semakin tepat (Ghozali, 2014).

\section{Uji Signifikansi Simultan (F)}

Model regresi dinyatakan layak jika angka signifikansi $\mathrm{F}$ pada tabel ANOVA $<0,05$. Dari hasil pengolahan data, nilai $F$ sebesar 22,258 dengan signifikansi $0,000<0,05$. karena nilai signifikansi lebih kecil dari 0,05 maka model regresi yang digunakan sudah benar atau diterima. Maka dapat disimpulkan bahwa model regresi dalam penelitian mampu memprediksi kualitas pengungkapan CSR yang berarti secara simultan atau bersama-sama variabel kapitalisasi pasar, kepemilikan institusional, komite audit, dan ukuran dewan komisaris berpengaruh terhadap pengungkapan CSR.

\section{PEMBAHASAN}

\section{Kapitalisasi Pasar Terhadap Pengungkapan Corporate Social Responsibility}

Kapitalisasi pasar memiliki tingkat koefisien regresi $(\beta)$ bernilai positif sebesar 0,008 dengan tingkat signifikan lebih kecil dari $\alpha$, yaitu sig. $0,000<\alpha(0,05)$. Berdasarkan hasil tersebut maka kapitalisasi pasar berpengaruh positif dan signifikan terhadap pengungkapan CSR, sehingga hipotesis $1\left(\mathrm{H}_{1}\right)$ diterima. Teori legitimasi menjelaskan perusahaan yang memiliki kapitalisasi pasar yang besar mempunyai keterkaitan lebih luas terhadap masyarakat dan para pemangku kepentingan sehingga perusahaan akan melaporkan informasi tanggung jawab sosial lebih rinci. Hal ini dilakukan oleh perusahaan untuk mendapatkan legitimasi dari masyarakat yang akan berdampak pada kelangsungan hidup perusahaan, sehingga semakin tinggi kapitalisasi pasar suatu perusahaan maka semakin tinggi pula tingkat pengungkapan CSR suatu perusahaan.

Hasil penelitian ini tidak sejalan dengan penelitian Rahayu dan Rahayu (2013) serta Deitina (2015) yang menyatakan bahwa kapitalisasi pasar tidak berpengaruh terhadap pengungkapan CSR. Namun hasil penelitian ini sejalan dengan penelitian yang dilakukan Sufian (2012) dan Indraswari Mimba (2017) yang menyatakan bahwa kapitalisasi pasar berpengaruh terhadap pengungkapan CSR.

\section{Kepemilikan Institusional Terhadap Pengungkapan Corporate Social Responsibility}

Kepemilikan institusional memiliki tingkat koefisien regresi $(\beta)$ bernilai negatif sebesar 0,032 dengan tingat signifikan lebih kecil dari $\alpha$, yaitu sig. $0,047<\alpha(0,05)$. Berdasaran hasil tersebut maka kepemilikan institusional berpengaruh negatif dan signifikan terhadap pengungkapan CSR, sehingga hipotesis $2\left(\mathrm{H}_{2}\right)$ ditolak. Penyebab kepemilikan institusional berpengaruh negatif dapat disebabkan karena investor institusional belum mampu dalam melakukan atau menjalankan pengawasan efektif terhadap kinerja manajemen dalam hal meningkatkan pengungkapan CSR.

Hal ini dapat disebabkan karena fokus investor institusional serta pemerintah baik didalam maupun diluar negeri adalah laba dari perusahaan yang akan berdampak pada return yang didapat oleh investor dari investasinya di perusahaan. Penyebab lainnya karena investor belum mempertimbangkan masalah pengungkapan CSR sebagai hal penting atau kriteria 
dalam menanamkan modal pada perusahaan, sehingga para investor institusional cenderung tidak memperhatikan tingkat persentase pengungkapan CSR dalam laporan tahunan perusahaan.

Hasil ini tidak sejalan dengan penelitian yang dilakukan oleh Majeed, dkk (2015), Nugroho dan Yulianto yang menyatakan bahwa kepemilikan institusional berpengaruh positif terhadap pengungkapan CSR. Namun penelitian ini sejalan dengan penelitian yang dilakukan oleh Sholihin, dkk (2018), Krisna dan Suhardianto (2016) yang menyatakan kepemilikan institusional berpengaruh negatif dan signifikan terhadap pengungkapan CSR.

\section{Komite Audit Terhadap Pengungkapan Corporate Social Responsibility}

Komite audit memiliki tingkat koefisien regresi $(\beta)$ bernilai positif sebesar 0,012 dengan tingat signifikan lebih besar dari $\alpha$, yaitu sig. $0,190>\alpha(0,05)$. Berdasarkan hasil tersebut maka komite audit berpengaruh positif dan tidak signifikan terhadap pengungkapan CSR, sehingga hipotesis $3\left(\mathrm{H}_{3}\right)$ ditolak. Hal ini dapat disebabkan dikarenakan Komite audit yang rata-rata 3 orang mengindikasikan bahwa pembentukkan anggota komite audit dimungkinkan hanya sebagai formalitas untuk memenuhi peraturan pemerintah saja. Penyebab lainnya dapat disebabkan oleh rendahnya fungsi pengawasan dari komite audit sebagai komite yang membantu dewan komisaris untuk mengawasi manajemen dalam pengendalian internal perusahaan dan transparansi pelaporan informasi keuangan maupun non keuangan, kurangnya pemahaman dari anggota komite audit akan peran pentingnya dan rendahnya independesi komite audit yang mana dimungkinkan anggota komite audit memihak salah satu pihak yang berkepentingan.

Hasil penelitian ini bertolak belakang dengan temuan peneliitian Sari et.al (2019) yang menemukan bukti empiris bahwa good corporate governance yang diproxikan dengan proporsi komite audit independen tidak berpengaruh signifikan terhadap luas pengungkapan lingkungan pada perusahaan manufaktur yang terdaftar di Bursa Efek Indonesia tahun 20132017. Temuan penelitian ini konsisten dengan temuan penelitian Krisna dan Suhardianto (2016), Pasaribu, dkk (2015), dan Khan, et al (2013) yang menyatakan bahwa komite audit berpengaruh terhadap pengungkapan CSR. Namun penelitian ini sejalan dengan penelitian yang dilakukan oleh Yusran, dkk (2018), Paramita dan Marsono (2014), Rizki, dkk (2014) yang menyatakan bahwa komite audit tidak berpengaruh terhadap pengungkapan CSR.

\section{Ukuran Dewan Komisaris Terhadap Pengungkapan Corporate Social Responsibility}

Ukuran dewan komisaris memiliki tingkat koefisien regersi $(\beta)$ bernilai posistif sebesar 0,005 dengan tingkat signifikan lebih kecil dari $\alpha$, yaitu sig. $0,008<\alpha(0,05)$. Berdasarkan hasil tersebut maka ukuran dewan komisaris berpengaruh posistif dan signifikan terhadap pengungkapan CSR, sehingga hipotesis $4\left(\mathrm{H}_{4}\right)$ diterima. Hal ini menunjukan bahwa dewan komisaris telah menjalankan tugasnya dengan baik sehingga fungsi pengawasan atas kegiatan perusahaan telah terlaksana dengan baik. Dewan komisaris mampu dalam memberikan saran kepada direksi untuk mengungkapkan kegiatan perusahaan baik itu kegiatan operasional maupun kegiatan lainnya seperti kegiatan tanggung jawab sosial perusahaan.

Hasil penelitian ini tidak sejalan dengan penelitian yang dilakukan oleh Jayanti dan Husaini (2018), dan Nurfadilah dan Sagara (2015) yang menyatakan bahwa ukuran dewan komisaris tidak berpengaruh terhadap pengungkapan CSR. Namun hasil penelitian ini sejalan dengan penelitian yang dilakukan oleh Yusran, dkk (2018), Susilo (2015), Pasaribu, dkk (2015) yang menyatakan bahwa ukuran dewan komisaris berpengaruh terhadap pengungkapan CSR. Hal ini berarti semakin banyak jumlah dewan komisaris maka semakin luas pengungkapan CSR dalam laporan tahunan perusahaan. 


\section{SIMPULAN, KETERBATASAN, DAN SARAN \\ Simpulan}

Berdasarkan hasil penelitian dan pengujian hipotesis yang telah dilakukan, maka penelitian ini dapat disimpulkan secara simultan menunjukan kapitalisasi pasar, kepemilikan institusional, komite audit dan ukuran dewan komisaris berpengaruh signifikan terhadap pengungkapan Corporate Social Responsibility. Hasil penelitian secara parsial menunjukan kapitalisasi pasar dan ukuran dewan komisaris berpengarih posistif dan signifikan terhadap pengungkapan Corporate Social Responsibility, sedangkan komite audit berpengaruh positif dan tidak signifikan terhadap pengungkapanCorporate Social Responsibility dan kepemilikan institusional berpengaruh negatif dan signifikan terhadap pengungkapan Corporate Social Responsibility

\section{Keterbatasan}

a. Hasil uji koefisien determinan dalam penelitian ini adalah 0.320 yang artinya bahwa konstribusi variabel independen hanya sebesar 32\%, sehingga masih banyak variabel lain yang dapat mempengaruhi pengungkapan CSR.

b. Variabel dewan komisaris yang digunakan dalam penelitian ini hanya digambarkan melalui jumlah anggota dewan komisaris.

c. Variabel komite audit yang digunakana dalam penelitian ini hanya diukur menggunakan jumlah anggota komite audit saja.

d. Sumber informasi CSR yang digunakan dalam penelitian hanya berasal dari laporan tahunan perusahaan sehingga tidak semua indikator CSR pada GRI G4 diungkapkan dengan jelas.

e. Periode penelitian yang digunakan hanya terbatas tiga tahun yaitu tahun 2013-2017.

f. Sampel penelitian hanya berpatokan pada perusahaan manufaktur

\section{Saran}

a. Variabel yang digunakan dalam penelitian ini dapat dikembangkan lebih lanjut seperti penambahan variabel lain misal variabel manajemen laba, sertifikat ISO 14001, likuiditas, kepemilikan saham publik dan kinerja lingkungan.

b. Variabel dewan komisaris sebagai fungsi pengawasan perusahaan selain menggunakan faktor jumlah anggota juga dapat menggunakan faktor-faktor lain seperti independensi dan jumlah rapat agar pengawasan perusahaan lebih komprehensif.

c. Variabel komite audit sebagai fungsi pengawasan perusahaan dapat menggunakan metode variabel dummy untuk pengukurannya agar mencerminkan kondisi yang sesungguhnya.

d. Sumber informasi untuk penelitian selanjutnya dapat menambah sumber diluar dari informasi laporan tahunan seperti dari laporan keberlanjutan.

e. Periode penelitian untuk peneliti selanjutnya dapat menambah periode penelitian misal 5-7 tahun sehingga nilai yang diperoleh lebih sesuai dengaan kondisi yang seharusnya.

f. Penelitian selanjutnya agar dapat menggunakan sampel berbeda, lebih luas dan tidak hanya terbatas pada perusahaan manufaktur agar dapat mencerminkan kondisi yang sesungguhnya.

\section{DAFTAR PUSTAKA}

Anggraeni, Dian Yuni dan Djakman, Chaerul D. 2017."Slack Resources, Feminisme Dewan, dan Kualitas Pengungkapan Tanggung Jawab Sosial Perusahaan". Jurnal Akuntansi dan Keuangan Indonesia. Vol. 14 No. 1. Hal 94-118.

Deitina, T. 2015." The Determinant of CSR Disclosure of Mining Industry Listed in Indonesia Stock Exchange". Asia Business Review. Vol. 5 No. 3. Hal 141-148 
Ghozali, Imam dan Anis Chariri. 2007.'Teori Akuntansi Edisi 4". Semarang: Badan Penerbit Universitas Diponegoro.

GRI. 2013. "Global Reporting Initiative”. Diperoleh 17 Maret 2019, dari www.Globalreporting.org.

Hikmah, Noor Chairina, dan Desilarina Rahmayani. 2011. "Faktor-Faktor yang Mempengaruhi Luas Pengungkapan Corporate Governance dalam Laporan Tahunan Perusahaan Perbankan yang Terdaftar di Bursa Efek Indoensia”. Simposium Nasional Akuntansi XIV Aceh 2011.

Indraswari, I.G.A.L dan Mimba, N.P.S.H. 2017. "Pengaruh Profitabilitas, Pertumbuhan Perusahaan, Kapitalisasi Pasar dan Kepemilikan Saham Publik pada Tingkat Pengungkapan CSR”. Jurnal Akuntansi Universitas Udayana. Vol.20 No. 2, 12191231.

Jayanti, Karina Ries dan Husaini, Achmad. 2018.'Pengaruh Good Corporate Governance dan Profitabilitas Terhadap Pengungkapan Corporate Social Responsibility: Studi pada Perusahaan Sektor Pertambangan yang Terdaftar di Bursa Efek Indonesia Tahun 20152016. Jurnal Administrasi Bisnis (JAB). Vol. 59 No.1

Khan, Arifur, Muttakin, Mohammad Badrul dan Siddiqui, Javed. 2013."Corporate Governance and Corporate Social Responsibility Disclosure: Evidence From an Emerging Economy”. J Bus Ethics. 114: 207-223.

Krisna, Adtya Dharmawan dan Suhardianto, Novrys. 2016. " Faktor-Faktor yang Mempengaruhi Pengungkapan Tanggung Jawab Sosial". Jurnal Akuntansi dan Keuangan Universitas Airlangga. Vol. 18 No. 2.ISSN. 1411-0288.

Laksamitaningrum, Ch. F. Dan Purwanto, A. 2013. "Analisis Pengaruh Karakteristik Perusahaan, Ukuran Dewan Komisaris dan Struktur Kepemilikan Terhadap Pengungkapan Corporate Social Responsibility: Studi Empiris pada Perusahaan Manufaktur yang Terdaftar di Bursa Efek Indonesia Tahun 2009-2011”. Diponegoro Journal of Accounting. Vol. 2 No. 3. Halm:1-10.

Luo, L. Q. Tang dan Y.C. Lan. 2013."Comparison of Propensity for Carbon Disclosure Between Developing and Developed Countries: A Resource Constraint Perspective”. Accounting Research Journal. Vol. 26 No.1. Hal 6-34.

Majeed, Sadia, Aziz, Tariq dan Saleem, Saba. 2015. "The Effect Corporae Governance Elements on Corporate Social Responsibility (CSR) Disclosure: an Empirical Evidence from Listed Companies at KSE Pakistan. Int.J. Financial Stud. ISSN. 2227-7072.

Ningsih, Radis Fitri. 2017. "Pengaruh Mekanisme Good Corporate Governance dan Manajemen Laba Terhadap Enviromental Disclosure”. Jurnal Akuntansi. Vol.5 No.2.

Nugraha, S.A., dan Andayani, D. (2013). "Faktor-Faktor yang Mempengaruhi Pengungkapan Corporate Social Responsibility pada Laporan Tahunan." Jurnal Ilmu dan Riset Akuntansi. Vol.2, No. 10.

Nurfadilah, Wandayani dan Sagara, Yusar. 2015."Pengaruh Good Corporate Governance, Karakteristik Perusahaan dan Regulasi Pemerintah Terhadap Pengungkapan Corporate Social Responsibility”. Akuntabilitas. Vol. VIII No.1. ISSN. 1979-858X. Hal 78-89.

Paramita, A. D. Dan Marsono. 2014."Pengaruh Karakteristik Corporate Governance Terhadap Luas Pengungkapan Corporate Social Responsibility”.Diponegoro Journal of Accounting. Vol.3 No.1.

Pasaribu, Rowland Bismark Fernando, Kowanda, Dionysia dan Kurniawan, Dian. 2015.” Pengaruh Earning Management dan Mekanisme Corporate Governance Terhadap Pengungpakapan Corporate Social Responsibility pada Emiten Manufaktur di Bursa Efek Indonesia”. Jurnal Riset Manajemen dan Bisnis. Vol. 10 No. 2. ISSN. 1907-7343. 
Rahayu, L., dan Rahayu, D.F. 2013.’Determinan Pengungkapan Tanggung Jawab Sosial di Negara Berkembang: Studi Empiris Perusahaan Manufaktur di Indonesia. Jurnal Ekonomi dan Bisnis Islam. Vol. 8 No 1, 83-92.

Rizki, Liza Aulia, Basri, Hasan dan Musnadi, Said. 2014.’Pengaruh Faktor Fundamental dan Mekanisme Corporate Governance Terhadap Pengungkapan Corporate Social Responsibility pada Perusahaan Manufaktur yang Terdaftar di Bursa Efek Indonesia". Jurnal Magister Akuntansi Pascasarjana Universitas Syiah Kuala. Vol. 3 No.3. ISSN. 2302-0164.

Sari, Wiwi Hawin; Agustin, Henri; Mulyani, Erly. (2019). Pengaruh Good Corporate Governance dan Kinerja Lingkungan terhadap Pengungkapan Lingkungan (Studi Empiris pada Perusahaan Manufaktur yang Terdaftar di Bursa Efefk Indonesia Tahun 2013-2017). Jurnal Eksplorasi Akuntansi, 1(1), Seri A, 18-34.

Sembiring, Eddy Rismanda. 2006. “ Karakteristik Perusahaan dan Pengungkapan Tanggung Jawab Sosial: Studi Empiris pada Perusahaan yang Tercatat di Bursa Efek Jakarta. Jurnal Maksi Universitas Diponegoro Semarang. Vol. 6 No. 1.

Sufian, M.A. 2012. "Corporate Social Responsibility Disclosure in Bangladesh". Global Journal of Management and Business Research. Vol. 12 No. 14, 149-155.

Susilo, Moch Septiawan dan Titik Midawati. 2015."Pengaruh Good Corporate Governance Terhadap Luas Pengungkapan Corporate Social Responsibility".Jurnal Ilmu dan Riset Akuntansi. Vol. 4 No. 5: 1-16.

Suwardjono. 2005. “ Teori Akuntansi Perekayasaan Pelaporan Keuangan”. Yogyakarta: BPFE Yogyakarta.

Terzaghi, Muhammad Titan. 2012. "Pengaruh Earning Management dan Mekanisme Corporate Governance Terhadap Pengungkapan Tanggung Jawab Sosial Perusahaan Manufaktur yang Terdaftar di Bursa Efek Indonesia". Jurnal Ekonomi dan Informasi Akuntansi (Jenius). Vol. II No.I: 31-47.

Wartyna, Erva dan Apriwenni, Prima. 2018.’Dampak Kinerja Lingkungan, Kepemilikan Institusional, Kepemilikan Publik, Leverage, ukuran Perusahaan dan Pertumbuhan Perusahaan Terhadap Pengungkapan Tanggungjawab Sosial"..Jurnal Akuntansi. Vol. 7 No. 1. ISSN. 2089-7219.

Yusran, Izza Ariqah R, Farida Titik Kristanti dan Wiwin Aminah.2018.’Pengaruh Indikator Good Corporate Governance Terhadap Corporate Social Responsibility Disclosure”. EProceeding of Management. Vol. 5 No.1. ISSN. 2355-9357 


\section{LAMPIRAN}

Descriptive Statistics

\begin{tabular}{|l|r|r|r|r|r|}
\hline & \multicolumn{1}{|c|}{$N$} & Minimum & Maximum & \multicolumn{1}{c|}{ Mean } & Std. Deviation \\
\hline CSR & 189 & .07 & .25 & .1263 & .04781 \\
KpPsr(Juta) & 189 & 30,100 & $6 . E 8$ & $26,482,9$ & $83,456,637.6$ \\
& 189 & 24.13 & 33.94 & 28.0776 & 68 \\
LN_KpPsr & 189 & .0001 & .8062 & .193741 & .1823348 \\
KpInst & 189 & 2 & 4 & 3.08 & .341 \\
KOMA & 189 & 2 & 12 & 4.55 & 1.928 \\
UDK & 189 & & & & \\
Valid N (listwise) & & & &
\end{tabular}

Model Summary

\begin{tabular}{|l|l|r|r|r|r|}
\hline $\begin{array}{l}\text { Mode } \\
1\end{array}$ & $\mathrm{R}$ & R Square & $\begin{array}{c}\text { Adjusted R } \\
\text { Square }\end{array}$ & $\begin{array}{c}\text { Std. Error of } \\
\text { the Estimate }\end{array}$ & $\begin{array}{c}\text { Durbin- } \\
\text { Watson }\end{array}$ \\
\hline 1 & $.571^{2}$ & .326 & .311 & .03968 & .756 \\
\hline
\end{tabular}

a. Predictors: (Constant), UDK, Kplnst, KOMA, LN_KpPsr

b. Dependent Variable: CSR

ANOVA

\begin{tabular}{|ll|r|r|r|r|r|}
\hline Model & & \multicolumn{1}{|c|}{$\begin{array}{c}\text { Sum of } \\
\text { Squares }\end{array}$} & \multicolumn{1}{c|}{ df } & Mean Square & F & Sig. \\
\hline 1 & Regression & .140 & 4 & .035 & 22.258 & $.000^{=}$ \\
& Residual & .290 & 184 & .002 & & \\
& Total & .430 & 188 & & & \\
\hline
\end{tabular}

a. Predictors: (Constant), UDK, Kplnst, KOMA, LN_KpPsr

b. Dependent Variable: CSR

\begin{tabular}{|c|c|c|c|c|c|c|c|c|}
\hline \multicolumn{9}{|c|}{ Coefficients $^{\mathrm{J}}$} \\
\hline \multirow{2}{*}{\multicolumn{2}{|c|}{ Madel }} & \multicolumn{2}{|c|}{ Unstandardized Coefficients } & \multirow{2}{*}{$\begin{array}{c}\begin{array}{c}\text { Standardized } \\
\text { Coefficients }\end{array} \\
\text { Beta } \\
\end{array}$} & \multirow[b]{2}{*}{$t$} & \multirow[b]{2}{*}{ Sig. } & \multicolumn{2}{|c|}{ Collinearity Statistics } \\
\hline & & B & Std. Error & & & & Tolerance & VIF \\
\hline \multirow[t]{5}{*}{1} & (Constant) & -.149 & .044 & & -3.387 & .001 & & \\
\hline & LN_KpPsr & .008 & .001 & .384 & 5.305 & .000 & .700 & 1.429 \\
\hline & Kplnst & -.032 & .016 & -.121 & -2.001 & .047 & .994 & 1.006 \\
\hline & KOMA & .012 & .009 & .087 & 1.316 & .190 & .837 & 1.195 \\
\hline & UDK & .005 & .002 & .204 & 2.693 & .008 & .641 & 1.561 \\
\hline
\end{tabular}

a. Dependent Variable: $\operatorname{CsR}$

\section{Coefficients}

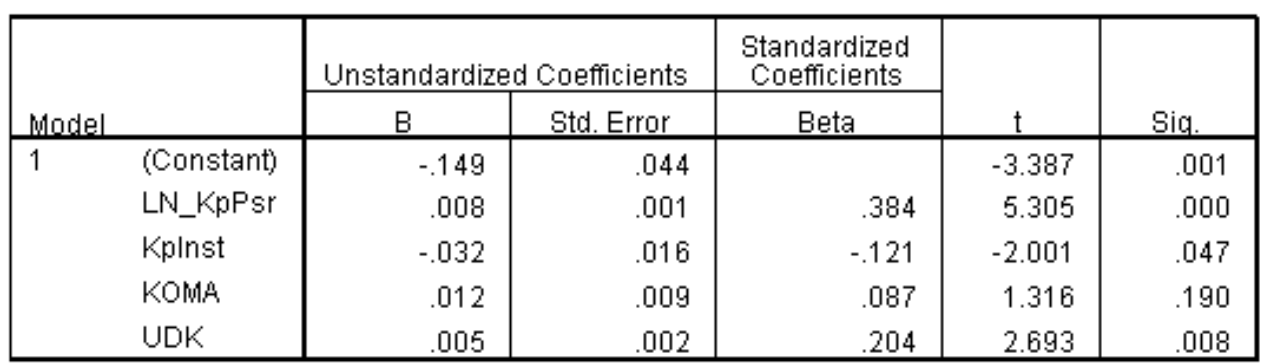

a. Dependent Variable: CSR 
Normal P-P Plot of Regression Standardized Residual

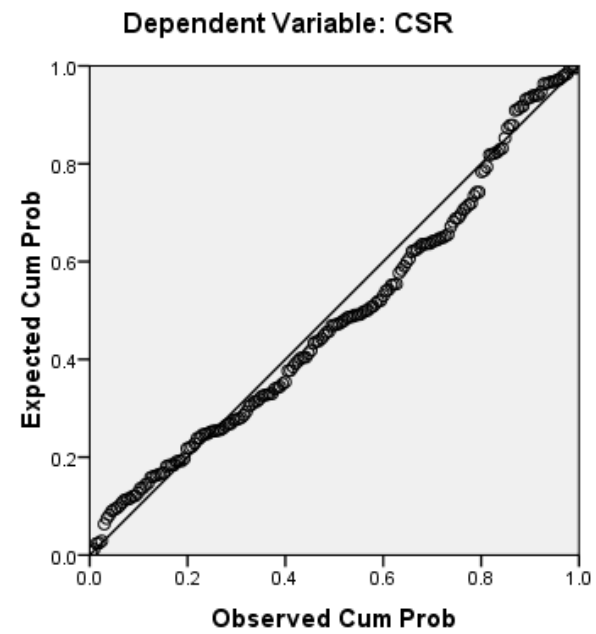

Scatterplot

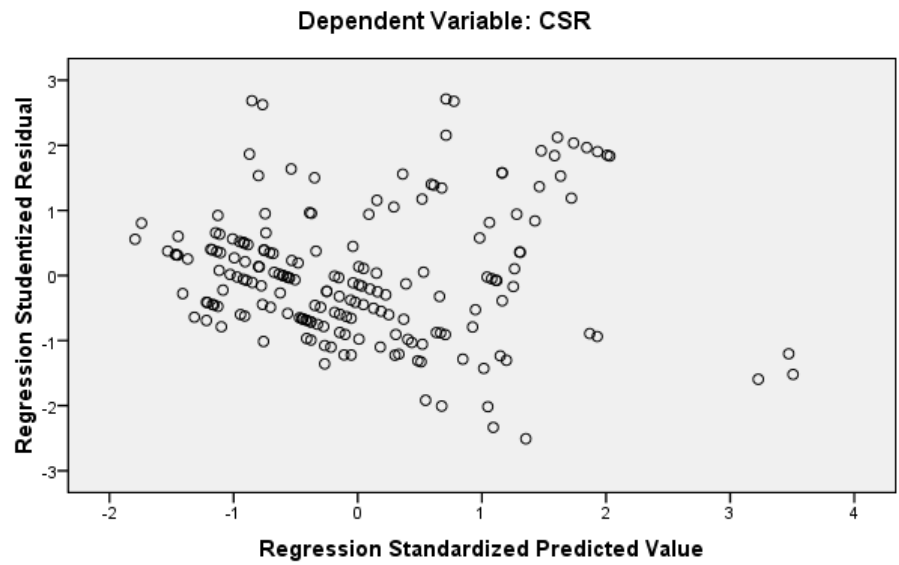

